\title{
IMPACT OF REMITTANCE IN WOMEN EDUCATION: AN EMPIRICAL STUDY
}

\author{
Bhaba Datta Sapkota* \\ Indra Mali Malakar*
}

\begin{abstract}
This study aims at exploring the impact of remittance on women's education while employing descriptive cum cross sectional rearch design. For this purpose, conveniently Raghuganga Rural Municipality, Ward no. 3, (Mauwaphant area), Myagdi District of Gandaki Province and to well represent the universe, 19 househols were randomly selected receiving the remittance. Fieldwork method including in-depth interviews, semi-structured questionnaires, focus group discussion, key informants interview, and case study were the basic tools used in this study for obtaining the primary data which were then analyzed by using simple statistical tools such as tabulation, classification, frequency and percentage. The study argues that remittance raises school enrollment, school completion rate, and private school enrollment and thus improving the educational status of women in general and girls in particular in comparison to the past and have brought the qualitative change in children;s educational status. It concludesthat remittance can lift budget constraints, thereby providing children in remittance-receiving households the opportunity to go to school and finally directly benefitsthe households. Wrapping up, this type of study is pertinent as it would attract public attention in terms of policy that could lead to extensive positive policy initiatives for more detailed discussions and their productive usages for crucial policy concern in Nepal.
\end{abstract}

Key Words: Gender inequality, labour migration, remittance, school enrollment and women education

\section{INTRODUCTION}

Remittance is not the latest topic of discussion used in development discourse (Karine, 2014); although, it is taken as a debatable issue in development economics. Workers' remittance is considered an indivisible part of social development, especially, in labour exporting countries (Al-Assaf, Al-Malki \&Abdullah, 2014). In Nepal, relatively, surplus labour is available in the rural agriculture sector, and most of them are not fascinated in regulating their traditional occupation i.e. subsistence agriculture, that's why they like to migrate to the overseas market where they get employment opportunities according to their capacity and skill. Due to the insufficient economic opportunities in the domestic market,

*Mr. Sapkota is an assistant professor of Rural Development, Patan Multiple Campus, TU, Nepal

*Mr. Malakar is an assistant professor of Population Studies, Patan Multiple Campus, TU, Nepal 
international labour migration got a top priority in the $21^{\text {st }}$ century in many developing countries.

Generally, remittance is a transfer of money by foreign migrant workers in their home country. It is the amount of money sent back to home countries by foreign migrant workers. It encompasses both monetary and non-monetary receive. Indeed, remittance is used to cover daily living expenses, to provide support in schooling the children, emergencies and making small investments (NRB, 2005). On the one hand, because of labour shortage, the socio-economic and cultural effect of labour migration can initially be negative in the place of origin. On the one hand, the positive impacts via remittance can be seen on expenditure and investment in different sectors such as education, health, culture, sanitation and livelihoods of remittance-receiving households (NRB, 2012). In course of development, it is taken as a major debatable issue between and among development practitioners all over the world (Karine, 2014).

Nepal received remittance equivalent to almost $25.1 \%$ of the country's total GDP in 2016 (MoF, 2018). Both economic and social remittance sent by the migrant workers to their home country play a yardstick role in both the national economy as well as individual households (Yang, 2008). There are abundant factors, which contribute notably to the upgrading of the living standard of a society. Nevertheless, some of these factors have a particular value in a specific community. Remittance is an imperative because it contributes noticeably to the economic strength of the households and overall economy in the receiving countries (Nasir, Tariq \&Rehman, 2016). Nepal received remittance amounting to Rs. 875 billion in fiscal year 2019/20, which translates into a remittance to gross domestic ratio of 23.23 percent (NRB, 2020).

There is a general view that remittance is mostly spent on consumption and is not used for productive investment that would have an impact on development in the long-run. This view ignores, however, that spending remittance on education and training is in fact, an investment in human capital. Many studies suggest that the use of remittance for education has significant socio-economic effects for individuals, their families and society at large (Kifle, 2007). In the Nepalese context, the impact of remittance has been examined on food consumption, health and education using the data set of NLSS-III, 2010/11. Remittance recipient households tend to spent more on consumption, health and education as compared to remittance non-receiving households (Thapa \& Acharya, 2017). The majority of women in the world have to face harder work problems as compared to men to secure their livelihoods. Owing to the patriarchal system in Nepal, women have low position in society and have less access to education, health, assets and productive resources. 
This study focused on how remittance affected the educational status of women in Nepalese society. Social justice of any society is guided by the access of people to education, particularly, women's education and their empowerment. In this scenario, this paper might be helpful to identify the issue of gender and education for success as per social integration. Therefore, this paper would be incredibly useful to identify the precise role of remittance for women's empowerment through better education. Further, this paper would be valuable mainly to the government, planners, policymakers and the concerned stakeholders who are directly or indirectly involved in women's education, empowerment and gender equality. Thus, the main objective of this paper is to assess the impact of remittance on women's education in the study area.

\section{METHODS AND MATERIALS}

This study uses descriptive cum cross-sectional research design and uses a critical approach on empirical findings based on the fieldwork method which was carried out in Raghu Ganga Rural Municipality, Myagdi District of Gandaki Province, Western Nepal selecting purposively. The proposed study area has 8 wards. For this study conveniently ward no. 3 , (Mauwaphant), of the rural municipality, was selected for investigating the impacts of remittance on women's education. There were 158 remittance recipient households and it was the universe of the study. Randomly 19 households were taken as a sample through a convenient sampling technique as it was more than 12 percent that could well represent the universe. Semi-structured questionnaire schedule, in-depth interview, focus group discussion, key informants, interview and case study were used as a tool for essential data collection. Simple statistical tools such as tabulation, classification, frequency, percentage and charts were used for data analysis and presentation.

\section{RESULTS}

\section{Population Composition by Age}

Population composition is the structural array of the different tendencies of demography such as male, female, child, caste, religion, occupational status etc. This study described only age that determines the economically active population.

\section{Table 1}

Population Compositions of the Sampled Households by Age

\begin{tabular}{|c|c|c|c|c|c|c|}
\hline Age ( in Year) & \multicolumn{1}{|l|}{ Male } & Percent & Female & Percent & Total & Percent \\
\hline $0-14$ & 19 & 35.84 & 21 & 34.42 & 40 & 35.08 \\
\hline $15-59$ & 26 & 49.05 & 35 & 57.37 & 61 & 53.50 \\
\hline 60 and above & 8 & 15.11 & 5 & 8.21 & 13 & 11.42 \\
\hline Total & 53 & 100 & 61 & 100 & 114 & 100 \\
\hline
\end{tabular}

Source: Field Survey, 2015 
Table 1 shows that the economically active population (15-59 years) accounts for 53.50 percent, which is the largest portion of the total population in the study area. Under the economically active population, females are 57.37 percent and males are 49.05 percent. It means the female portion in economically active is greater than that of male. The composition of the economically active population is high in the study area which shows a higher tendency to international labour migration and inflow of remittance.

\section{Educational Status}

Education is the third eye of human beings. It is a lifelong process by which people can improve their living standards. The level of human development of a society is determined by the literacy rate and good schooling trend.

Table 2

Educational Status of the Sampled Households

\begin{tabular}{|l|c|c|c|c|c|c|}
\hline Particulars & Male & Percent & Female & Percent & Total & Percent \\
\hline Literate & 44 & 83 & 41 & 77 & 85 & 74.5 \\
\hline Illiterate & 9 & 17 & 20 & 23 & 29 & 25.5 \\
\hline \multicolumn{1}{|c|}{ Total } & 53 & 100 & 61 & 100 & 114 & 100 \\
\hline
\end{tabular}

Source: Field Survey, 2015

Table 2 shows that 83 percent of the male are literate and only 17 percent of males are illiterate. Likewise, 77 percent of the female are literate and the remaining 23 percent are illiterate. In the study area, owing to access to schools and the inflow of remittance, educational status is seen as better than the national average. According to the census of 2011, the literacy rate of Nepal is 65.9 percent whereas the literacy status of the study area is approximately 75 percent. There exists strong and positive reform in women's education. Compared to past, women education pattern is gradually increasing. In the past, there were no such opportunities for women's education but nowadays the schooling trend has been changed; it is because of international migration and inflow of remittance. It is verified by the opinions of the local respondents. It is concluded that both the social and economic status of the respondents have changed by both monetary and social remittance. Remittance recipient households have been well known how to mobilize the received remittance (money, skill, knowledge, ideas, technology, opinions, experiences etc.) by their migrant members from abroad on productive sectors particularly women education.

\section{School Enrollment Pattern}

Generally, there are two types of educational institutions, namely, private and government. It is assumed that private schools/colleges teach in English medium, which is more 
expensive, whereas government schools/colleges teach in Devanagari (Nepali) medium, which is cheaper than private in terms of expenses.

Table 3

Student Enrollment Pattern in Schools/Colleges

\begin{tabular}{|l|l|l|l|l|l|l|}
\hline $\begin{array}{l}\text { Nature of } \\
\text { Schools/Colleges }\end{array}$ & Male & Percent & Female & Percent & Total & Percent \\
\hline Private & 16 & 57.14 & 10 & 31.25 & 26 & 43.33 \\
\hline Government & 12 & 48.86 & 22 & 68.75 & 34 & 56.67 \\
\hline Total & 28 & 100 & 32 & 100 & 60 & 100 \\
\hline
\end{tabular}

Source: Field Survey, 2015

It is found that out of 60 students, 26 (43.33 Percent) are studying in private schools/colleges and the remaining 34 (56.67 Percent) are enrolled in government schools. When we break through the male and female, 31.25 percent females are studying in private schools and 68.75 in the government schools. These figures show that the remittance is used in women's education except other heads like land purchase, buying luxurious goods (gold, silver, television, and mobile etc.), health and sanitation. The number of female students' enrollment in government schools/colleges is more than that of private institutions in comparison to male students i.e 68.75 percent female students and 48.86 percent male students are studying in government schools/colleges whereas the number of female students in private schools/colleges is lesser than that of male students i.e. 31.25 percent female students and 57.14 percent male students are studying in private schools/colleges.

Slowly and gradually society gets reformed in women's education. In this sense, remittance has played a positive role in women's education and empowerment. It is found that the level of understanding from the gender perspective of development was widening among the parents, which is equivalent to migration nexus development.

\section{Narrative Description of Key Informant Interview}

Shanti Sharma (aged 40), President of a progressive women group (Aama Samuha) gave lots of arguments on remittance and their implication for girl's education. The remittance recipient households have taken good decisions to enroll their daughter in school. "I have seen lots of socio-economic changes in our community that are brought not by other factors but by both monetary and social remittance, she said. The ordinary households who receive remittance use it in different sectors although the first priority is given to child education. Nowadays, slowly and gradually, ordinary households have started to invest on daughter's education. She said, local remittance recipient households clearly understood: remittance is not a sustainable source of income. Consequently, according to her opinion, remittance should be used in the productive sector. Further, she said, investment in women's education is a major pivot of social change and gender equality. Investment in 
women's education, indeed, makes them self-confident and independent. In our society, even in my family too, there is a trend to enroll girls into government school and sons into private school but I have challenged this trend. Hence, I hereby strongly recommend 'enhancing the women's education is inevitable for gender equality in developing society like Nepal'.

\section{Impact of Remittance on Women Education}

Nepal, being a patriarchal society, there exists unequal access to education between male and female. Relatively, males are more educated than females. It can be proved through the national literacy rate i.e 75.1 percent of the male are literate and 57.4 percent of the females are literate (CBS, 2011). Kamala Sharma (aged 50), a secondary school teacher at Raghuganga Higher Secondary School, is involving for 25 years. She said "in my childhood time, very few daughters get chance to read and write. I am lucky enough to have an education with my brothers. Fortunately, I got a chance to join a school. But my friends (girls) have not got chances to education. They are compelled to child marriage (below 15 years).

Further, she added the views of the present stage of society regarding women's education. There are a lot of private and governmental schools/colleges were running to reduce the illiteracy rate. Even the government also planned education for all. In this scenario, she perceived as "nowadays the situation is just opposite that of my schooling time. Many families treat sons and daughters equally. Son and daughter both are getting the opportunity of education either in a private school or government school. I have also observed that migrant's family faced less problem of money, have learned international experiences, knowledge, skills etc as inputs for enhancing the quality of life of family including women member. Now even daughter-in-law also get a chance to continue their education (which was impossible in past) because of sound economic status (by the remittance). Similarly, dropout ratio of girl child from our school reduced gradually in present days."

\section{Table 4}

\begin{tabular}{|l|l|l|l|l|l|l|l|l|}
\hline \multirow{2}{*}{ Nirls' School Enrollment Trend } \\
\cline { 2 - 11 } & \multicolumn{7}{|c|}{ Number of Girl Student in Each Year } \\
\cline { 2 - 11 } & 2007 & 2008 & 2009 & 2010 & 2011 & 2012 & 2013 & 2014 \\
\hline Malika Devi Lower Secondary School & 150 & 163 & 167 & 175 & 181 & 188 & 192 & 201 \\
\hline AmarSingh Primary School & 79 & 85 & 89 & 91 & 99 & 105 & 110 & 116 \\
\hline Gyanodaya Secondary School & 203 & 209 & 221 & 225 & 236 & 244 & 250 & 261 \\
\hline Himalaya Primary School & 52 & 59 & 62 & 69 & 75 & 81 & 90 & 97 \\
\hline Raghuganga Higher Secondary School & 185 & 192 & 199 & 205 & 216 & 225 & 239 & 252 \\
\hline Total & 669 & 708 & 738 & 765 & 807 & 843 & 881 & 927 \\
\hline
\end{tabular}

Source: Field Survey, 2015 
Within the period of 8 years (2007 -2014), the number of girl students increased from 669 in 2007 to 927 in 2014. The increasing number of a girl student in school showed that the migrant's family was giving more importance to daughter education. The main reason behind it was the flow of remittance sent back to the home at origin by migrants from abroad. The increasing number of a girl student in school showed the positive thought of family, a community in education as well as the amount of investment was increased for women education. Hence, remittance play a positive role in women's education and socioeconomic development.

\section{DISCUSSION}

Today, an inflow of remittance is not only an issue of developing countries but it is a serious issue, how it is used for daily life by the recipient households too. Remittance has implications for education and other areas of socio-economic policy. The increasing flow of remittance has a direct effect to reduce the disparity and inequality existing in society, reducing poverty and balance in the socio-economic condition of families (WB, 2011). This study also found that local remittance recipient households change their socio-economic status including women's education, community participation, reducing hunger and malnutrition and social awareness. International studies have suggested that both monetary and social remittance are the driving forces for enhancing the educational status of women. Calero, Bedi and Sparrow (2008) find that remittance increase school enrollment among girls and poor, in the ages 10-17. Mansuri's work on Pakistan was published (2006) finds remittance to have a positive effect, especially for girls, aged 5-17. As per the international experiences, in this study, the number of girl students increased from 669 in 2007 to 927 in 2014.The majority of women also reported that the migratory experience had improved their knowledge and self-esteem (Bhadra, 2007). A study based on a survey of 4000 households (UNDP, 2010) gives an idea of expenditure and effects of remittance. In this consideration, it is important to know how households use remittance and how they may impact the economy of Kosovo. It was suggested that remittance not only affects positively the level of income but also the ability to access education. This study also explores the increasing pattern of women's education at present as compared to the past; it is because of international migration and inflow of remittance.

\section{CONCLUSION}

Remittance affects the income level of the households as well as society. This study analyzes the impact of remittance on women's education. This study found that many of the respondents viewed as their migrant member sent remittance (monetary or social) used for uplifting socio-economic status including women'seducation. Remittance not only has a positive effect on the school enrollment ratio but also have a positive effect on the quality of education. The level of awareness among respondents to the use of remittance on women's 
education has gradually increased. Hence, people are being benefitted from monetary and social remittance sent back by fellow migrants like improvement in education, knowledge, skill, habits, social and political empowerment, and gender equality. Hence, as much as possible remittance should be used on human resource development and productive sector particularly in women education. By bringing appropriate policy measures concern agencies or stakeholders should encourage remittance-recipient households to use their money in women's education and empowerment. Foreign employment shall be developed as a tool for transferring social remittance.

\section{ETHIC AND CONSENT DISCLAIMER}

To ensure the privacy of all the participants, pre-informed verbal consent was taken as well as confidentially was maintained during the entire process of study. Ethical approval for the study was carried out from the Rector's Office's Research Division of Tribhuvan University.

\section{REFERENCES}

Adhikari, et.al. (2008). Foreign labour migration and remittance in Nepal: Policy, institution and services. International Food Policy Research Institute.

Al-Assaf, G., \& Al-Malki, Abdullah, M. (2014). Modeling the macroeconomic determinants of workers' remittance: The case of Jordan, International Journal of Economics and Financial Issues, Vol. 4, issue 3, p. 514-526.

Aomar Ibourk, A.,\& Amaghouss, (2014). Impact of migrant remittance on economic empowerment of women: A macroeconomic investigation, International Journal of Economics and Financial Issues Vol. 4, No. 3, 2014, pp.597-611

Bhattarai, P. (2005). Migration of Nepalese Youth for foreign employment: Problems and prospects (A Review of existing government policies and Programmes), Youth Action Nepal.

Brilleau, A., Coulibaly, S., Gubert, F., Koriko, O., Kuepie, M. \& Ouedraogo, E. (2005). Le secteurinformel: Performances, insertion, perspectives, enquête 1-2-3, phase 2, Revue Statéco, 99.

Central Bureau of Statistics, (2011). Nepal population census, 2011. National planning commission secretariat, Central Bureau of Statistics.

Central Bureau of Statistics, (2011). Nepal living standard survey (2010/11). National Planning Commission Secretariat, Central Bureau of Statistics.

Central Bureau of Statistics, (2012). A year book of Nepal, National Planning Commission Secretariat, Central Bureau of Statistics.

Gaudel, Y.S. (2006). "Remittance income in Nepal: Need for economic development." The Journal of Nepalese Business Studies.Vol. III (1). PP. 9-17.

Goldin, C. (1990). Understanding the gender gap:An economic history of American Women. Oxford University Press.

Haas, de Hein, (2008). Migration and development: A theoretical perspective, International Migration Institute. Oxford University Press. 
Haas, de Hein, (2012). Migration and development pendulum: Article Review on Research and Policy. International Migration Institute, Oxford University Press.

Karine, M. K. (2014). The impacts of remittance on developing countries, directorate-general for external policies of the union policy department.WIB 06 M 049 rue Wiertz 60 B-1047 Brussels.

Kifle, T. (2007). Do remittance encourage investment in education? Evidence from Eritrea, Ann Arbor, MI: M Publishing, University of Michigan Library.

Kothari, C.R.(2007). Research methodology: Methods and techniques. New age International (P) Limited.

Ministry of Finannce (2017). Economic survey (2016/2017).Government of Nepal, Ministry of Finance.

Nepal Rastra Bank. (2005). Main economic indicators (May-July), Monthly Report.Nepal Rastra Bank, Research Department.

Nepal Rastra Bank. (2012). Impact evaluation of remittance: A case study of Dhanusha District. Banking Development and Research Unit.

Nepal Rastra Bank. (2020). Current macro economics \& financial situation. Nepal Rastra Bank. Retrieved from https://www.nrb.org.np/red/current-macro economic-\&- financialsituation-tables-based-on-annual-data-of-2019-20\%.

Seddon, D. (2005). "Nepal's dependence in exporting labor." Available in: http://www.migrationinformation.org/Profiles/display

Seddon, et.al.(2000). “Foreign labor migration and the remittance economy of Nepal.” Final report submitted to DFID, Overseas Development Group, University of East Anglia.

Thapa, S. \& Acharya, S. (2017).Remettances and households expenditure in Nepal: Evedence from cross sectional data. Economies 5 (2)16.

UNFPA, (2006). World population monitoring, focusing on international migration and development: Report of the Secretary-General (E/CN.9/2006/3). ONU.

Van Rooij, A. (2000), Women of Taghzoute: The effects of migration on women left behind in Morocco. IMAROM working paper series no. 12. University of Amsterdam.

World Bank. (2005). Global development finance: Managing finance and managing vulnerability. The World Bank.

World Bank. (2011). "Migration and remittance factbook, 2011. ( $2^{\text {nd }}$ ed)." The World Bank.

Yang, D. (2008). "International migration, remittance \&household investment: Evidence from Philippine Migrants exchange rate shocks”.The Economic Journal, 118(528): 591-630. 